\title{
Household and Socio-cultural factors in Maternal Health in Rural areas of Northern Cross River State, Nigeria
}

DOI: 10.36108/NJSA/2102/01(0170)

\author{
Uche C. Isiugo-Abanihe \\ Department of Sociology \\ University of Ibadan \\ \& \\ David B. Ugal \\ Department of Demography and Social Statistics \\ Joseph Ayo Babalola University \\ Ikeji-Arakeji, Osun State
}

Vol. 10 Issue 1, 2012

\begin{abstract}
The study investigates household and socio-cultural factors that predispose women to high morbidity and mortality in rural Northern Cross River State. The study design utilized the survey research approach involving a sample of 823 respondents drawn from an estimated total population of 842,561 women. Multi-staged sampling procedure was used to select sampling units. Data were subjected to chi-square and logistic regression analysis. The socio-economic status of women played a significant role in maternal health; ever married women had better health status than those that were single; women who had their first babies earlier than the age of 20 had poorer health status relative to those who had them later. Household sanitation and hygiene behaviour were significantly related to maternal health status. Households with poor waste disposal systems reported poorer health status relative to those with better waste disposal systems. Some cultural practices such as early marriage, patriarchy and exposure to intimate partner violence have significant negative relationship with maternal health. Maternal health is the result of cumulative effects of household factors, cultural practices, attitudes and behaviours; improving the household and communal environment could significantly improve maternal health. This could be enhanced through improvement of health services and dissemination of health information in the rural communities which will properly educate women and empower them to resist obnoxious culture-bound factors that undermine their health.
\end{abstract}

Keywords: maternal health, household decision-making, domestic violence, health facilities, Cross River State

\section{Background of the Study}

Despite broad approaches towards improving maternal health globally, there is still a slow decline in maternal mortality and morbidity in less developed countries. According to UNICEF, UNFPA and WHO (2000), there are at least 529,000 maternal deaths in the world annually. These deaths are almost equally divided between Africa $(251,000)$ and Asia $(253,000)$, with only about $4 \%$ $(22,000)$ occurring in Latin America and the Caribbean. Less than $1 \%(2,500)$ occurs in the more developed regions of the world. Every minute a woman dies in pregnancy and childbirth. Each year more than 536,000 women die due to 
complications developed during pregnancy and childbirth (WHO, UNICEF, UNFPA and the World Bank, 2007). Apart from these deaths, United Nations (2007) reported that 10 million more suffer debilitating illnesses and lifelong disabilities. Seventy-five percent of these deaths occur during childbirth and the postpartum period. The vast majority of maternal deaths are avoidable when women have access to vital health care before, during and after childbirth (United Nations, 2007).

The 2008 Nigeria Demographic and Health Survey (NDHS) observed that maternal mortality depends largely on the environment where women of reproductive age live and whether they have access to information, education and communication resources they need to provide themselves with adequate care. Researchers are, therefore, interested in identifying and studying factors that contribute to high maternal morbidity and mortality in Nigeria.

Factors such as culture and socio-economic variables were found to be important determinants of maternal health in many societies (Caldwell, 1979, Mosley \& Chen, 1984; Gyimah 2002). Ujah et al. (2005) stated that in most areas of sub-Saharan Africa, social restructuring has promoted dangerous inequality. The most effects of these inequalities are on education, maternal and child health; while families are suffering the negative consequences of these many factors and conditions, women are in a particularly vulnerable position because, both by definition and default, they suffer the most of all these ill effects. One of these ill effects is the severe stress of pregnancy and childbirth.

The relevance of this study derived from the fact that demographic studies on the effect of household and socio-cultural conditions on maternal health have been very limited in the study area. The present study attempts to fill this intellectual gap by providing empirical explanation for the rate of maternal morbidity and mortality in the area. It also provides an epistemological explanation for the loss of useful data in previous demographic studies that lumped maternal health data into two categories of good and bad or favourable and unfavourable (Ross et al., 2002; Diallo, 2005; Ross et al., 2005).

Studies have shown that maternal health is not only the result of direct, biomedical conditions but also a function of household environmental conditions and other factors deeply rooted in culture, structure, institutional and gender relationship (Kyomuheudo, 2004). The issues raised above are crucial to the understanding and appreciation of maternal health in the study area. Hence, the main research question is "what are the effects of household and sociocultural conditions on maternal health among rural women in Northern Cross River State of Nigeria? This main question can be delineated into the following:

- How does the household structure/status affect maternal health?

* What role does the socio-economic status of women play in maternal health? 
* To what extent does household decision making affect maternal health?

* What are the communal practices that affect maternal health?

* How does domestic violence affect maternal health?

The main objective of the study is to examine the household and sociocultural conditions affecting maternal health among rural women of Northern Cross River State. To achieve this the following specific relationships are examined: household structures and conditions that affect maternal health; the effect of communal practices on maternal health; the effect of household decision and domestic violence on maternal health; and the relation between women's socioeconomic status and maternal health status.

\section{Methodology}

The study adopted the descriptive and exploratory designs that allowed the collection of data from a part or sub-set of a population whose analyses can be generalised on the entire population. The study employed quantitative and qualitative instruments to explore the role of the cultural environment of the household on maternal health. The Local Government Areas (LGAs) that make up Northern Cross River State are located in the Northern part of the state. They are bounded in the north by Benue State; in the south by the Boki LGA of Cross River State; in the east by Cameroun, and in the west by Ebonyi State. The area covers a large land mass of over 1000 square miles with a total population of over 2 million (NPC 1991). The area is divided into two main geographical zones. To the south is the thick rain forest belt which surges northwards to the foot of the hills that dominate the eastern and north-eastern part of the area. To the north is the savannah belt into which the southern forest zone gently merges.

Multistage sampling procedure was adopted. It began with the purposive selection of the Northern part of Cross River State. This part of the state has five LGAs, and was clustered into political wards. The LGAs were delineated into council headquarters, generally seen as urban and other areas, with absence of electricity, pipe borne water, etc, defined as rural. The study population included a cross-section of women of reproductive age 15-49. The sample was selected using Cochran's sample size formula. This method uses the "risk the researcher is willing to study"; commonly called the "Margin of error the researcher is willing to accept at a particular alpha level (i.e. 0.05 or 0.01 )". The formula is

$$
n_{0} \frac{(t)^{2} *(s)^{2}}{(d)^{2}}
$$


where $n_{0}=$ required sample size, $\mathrm{t}=$ value for selected alpha level of .05 in each tail. (The alpha level of 0.05 indicates the level of risk the researcher is willing to take that true Margin of error may exceed the acceptable margin of error).

$S=$ estimate of standard deviation in population

$d=$ estimate of variance deviation for 5 point scale or acceptable margin of error for mean being estimated (number of points on primary scale, acceptable margin of error).

$$
\begin{aligned}
& =\frac{(2.97)^{2}(12.20)^{2}}{(1.671)^{2}} \\
& =\frac{8.76 \times 148.84}{1.36}=954.5=955
\end{aligned}
$$

After deriving the sample size of 955, it was distributed among the households (Cochran, 1977). However, where a household had more than one ever-pregnant woman, a simple random sampling method of lucky dip procedure was adopted to select the one that was finally interviewed or administered with a questionnaire.

The major survey instrument was the structured questionnaire. The designing of the questionnaire was based on the pilot study that revealed the salient variables that influence maternal health. The survey instrument was cross-sectional and it adopted the Self-reported Morbidity Prevalence Questionnaire (SRMPQ). This method has been shown to be a very good approach in estimating the prevalence of morbidity using different administration schedules that employed disease lists beyond symptom labels. It also classified individuals within disease categories based on symptoms profiles. To measure morbidity, a maternal morbidity prevalence index was used to classify the population into three groups of roughly equal sizes. This was based on a proxy for morbidity determined by the prevalence of morbidity or else symptom list. The three categories were good maternal health (no report of symptoms of illness), moderate maternal health (1 report of symptom of illness) and poor maternal health ( 2 or more report of symptoms of the list of illnesses). This was done for self- reported illnesses and diagnosed illnesses. This method was used by Mechanic \& Newton, (1996; Zakpa et al., 1996; Woolsey, 1999; Sadana, 2000). The study explored maternal morbidity as an indicator rather than focusing on mortality because those situations in the childbearing women's lives that were threatening are the same problems that resulted in maternal death.

The questionnaire was administered by trained field assistants under the supervision of Research Coordinators who visited different parts of the study area, and ensured quality control. The data collected were edited to eliminate inconsistencies that may undermine content validity. The sample for the quantitative survey was sex-specific given the nature of the phenomenon under 
investigation. However, since pregnancy is the result of the interaction of women and men, the latter were included in the qualitative aspect of the study, which is not analyzed here. Out of 955 questionnaires administered among women aged 15 and above, 823 were found usable and analyzed in this study. The analysis was undertaken at univariate (frequency analysis), bivariate (chisquare analysis) and multivariate (logistic regression) levels.

\section{Results}

\section{Socio-Demographic Characteristics of Respondents}

The sample population has a mean age distribution of 33.6 years. Table 1 displays the percentage distribution of the respondents with respect to selected socio-demographic variables. The Table shows that the proportion of the respondents increases as age increases, from 6.7 percent aged below 19 years to about 18 percent aged 30-34, and thereafter declines. The predominance of currently married women in the sample is borne out by the fact that more than 70 percent of the women are currently married. Another 10.4 percent are currently either divorced or separated, while 8.3 percent are widowed. Over 10 percent of the women are single. With respect to formal schooling, the Table indicates that 35.5 percent of the women have no schooling and 29.2 percent have only primary education. Nearly 28 percent of the women have some secondary school education, while about 20 percent have some tertiary education. In other words, nearly half of the women have some secondary education or above which is relatively high for a rural area.

About 70 percent of the respondents are either traders or farmers and only 24 percent are civil servants. Most women in the study area engage in occupations that require little or no educational qualification. An examination of the monthly incomes of respondents shows that earnings are low in the study area. While 35.6 percent earn less than N1000 a month, 27.6 percent earn between N2000-N5000. The mean income for the respondents is N2, 854. This places an average woman in this area at less than three dollar a day. The mean age at first birth is 18 years, an indication that women in the study area do marry and have their first babies early. The Table shows that 11.4 percent of women had their first babies when they were less than 15 years, and another 36 percent between age 15 and 19 . 
Table 1: Percentage distribution of respondents by selected sociodemographic characteristics

\begin{tabular}{|c|c|c|c|}
\hline Characteristics & Categories & Frequency & Percentage \\
\hline & $<19$ & 55 & 6.7 \\
\hline & $20-24$ & 103 & 12.5 \\
\hline \multirow[t]{7}{*}{ Current age } & $25-29$ & 146 & 17.8 \\
\hline & $30-34$ & 148 & 17.9 \\
\hline & $35-40$ & 116 & 14.1 \\
\hline & $41-44$ & 116 & 14.1 \\
\hline & $45+$ & 139 & 16.9 \\
\hline & Single & 89 & 10.9 \\
\hline & Married & 580 & 70.5 \\
\hline \multirow[t]{4}{*}{ Marital status } & Divorced & 52 & 6.3 \\
\hline & Separated & 34 & 4.1 \\
\hline & Widowed & 68 & 8.3 \\
\hline & No Schooling & 193 & 23.5 \\
\hline \multirow[t]{4}{*}{ Education } & Primary & 240 & 29.2 \\
\hline & Secondary & 228 & 27.7 \\
\hline & Tertiary & 162 & 19.7 \\
\hline & Trader & 207 & 25.2 \\
\hline \multirow[t]{4}{*}{ Occupation } & Farmer & 363 & 44.1 \\
\hline & Civil servant & 199 & 24.2 \\
\hline & Others & 54 & 6.6 \\
\hline & $<\mathrm{N} 1,000$ & 293 & 35.6 \\
\hline \multirow[t]{5}{*}{ Monthly income } & $\mathrm{N} 2,000-\mathrm{N} 5,000$ & 227 & 27.6 \\
\hline & N6, $000-\mathrm{N} 10,000$ & 160 & 19.4 \\
\hline & $\mathrm{N} 11,000-\mathrm{N} 15,000$ & 87 & 10.6 \\
\hline & $>\mathrm{N} 16,000$ & 56 & 6.8 \\
\hline & No response & 28 & 3.4 \\
\hline \multirow[t]{4}{*}{ Age at first Birth } & $<15 \mathrm{yrs}$ & 94 & 11.4 \\
\hline & $15-19 \mathrm{yrs}$ & 293 & 35.6 \\
\hline & $20+$ & 408 & 49.6 \\
\hline & Total & 823 & 100.0 \\
\hline
\end{tabular}

\section{Harmful Communal Practices}

Some harmful traditional practices were examined for their possible effect on maternal health. These include female circumcision, child sex preference, strong patriarchy structures reflected in poor self-perception, and early age at marriage. The results are shown in Table 2. The Table reveals the high prevalence of female circumcision or genital mutilation, especially that involving complete removal of the genitalia $(58.1 \%)$ relative to partial removal $(41.9 \%)$. The timing of genital mutilation in this population is mainly at first pregnancy $(75.7 \%)$ rather than that performed at infancy. The table further shows that about one-third of the women support female genital cutting.

A majority of the women operate in a strong patriarchal setting which consigns women to low status, and engenders poor self-perception $(57.6 \%)$. 
More than 75 percent of the women expressed preference for a particular sex of child; in other words, they will continue to have more babies until they have the desired sex combination of children. The Table also shows that about 41 percent of the women married when they were age 15 or lower, an indication of early age at marriage in this population.

Table 2: Distribution of respondents by communal practices

\begin{tabular}{|c|c|c|}
\hline Practice & Frequency & Percent \\
\hline \multicolumn{3}{|c|}{ Type of female circumcision undergone } \\
\hline Complete removal & 478 & 58.1 \\
\hline Partial removal & 345 & 41.9 \\
\hline \multicolumn{3}{|l|}{ Timing of circumcision: } \\
\hline As Babies & 200 & 24.3 \\
\hline As young pregnant women & 623 & 75.7 \\
\hline Support for female circumcision & 264 & 32.0 \\
\hline Displayed poor self perception & 474 & 57.6 \\
\hline Support child sex preference & 620 & 75.3 \\
\hline \multicolumn{3}{|l|}{ Age at marriage: } \\
\hline $16+$ & 489 & 106 \\
\hline$<15$ & 334 & \\
\hline Total & 823 & 100.0 \\
\hline
\end{tabular}

\section{Domestic Violence}

Domestic violence refers to all language and actions that violate one's physical body, sense of self and trust. It involves threats or acts of inflicting physical, sexual and psychological harm. Prevalence of these in a household is likely to influence and determine the health status of those who are at the receiving end. The data in this section show that domestic violence is prevalent and its incidence is mainly against women; this invariably negatively affects maternal health. The data show that about 85 percent of women who participated in this study have suffered one form of violence or the other in the hands of their husbands or a close male partner. About 27 percent of the women have either been slapped or beaten by their spouses (see Table 3 ).

Table 3: Distribution of respondents by incidence of intimate partner violence

\begin{tabular}{lcc} 
Which of these has your husband done to you? & Frequency & Percent \\
\hline No Response & 129 & 15.7 \\
Quarreled with me & 463 & 56.3 \\
Slapped me & 111 & 13.5 \\
Beat me & 110 & 13.4 \\
Broke my bone & 10 & 1.3 \\
Total & 823 & 100.0 \\
\hline
\end{tabular}


The most dominant justification for intimate partner violence is in line with the findings of the Nigerian Demographic Health Survey (2003:14). About 30 percent of the women who took part in the study accepted that 'a man was justified in beating his wife if she goes out without telling him,' and about 15 percent if 'she argues with him' or 'refuses sex with him' (See Fig 1).

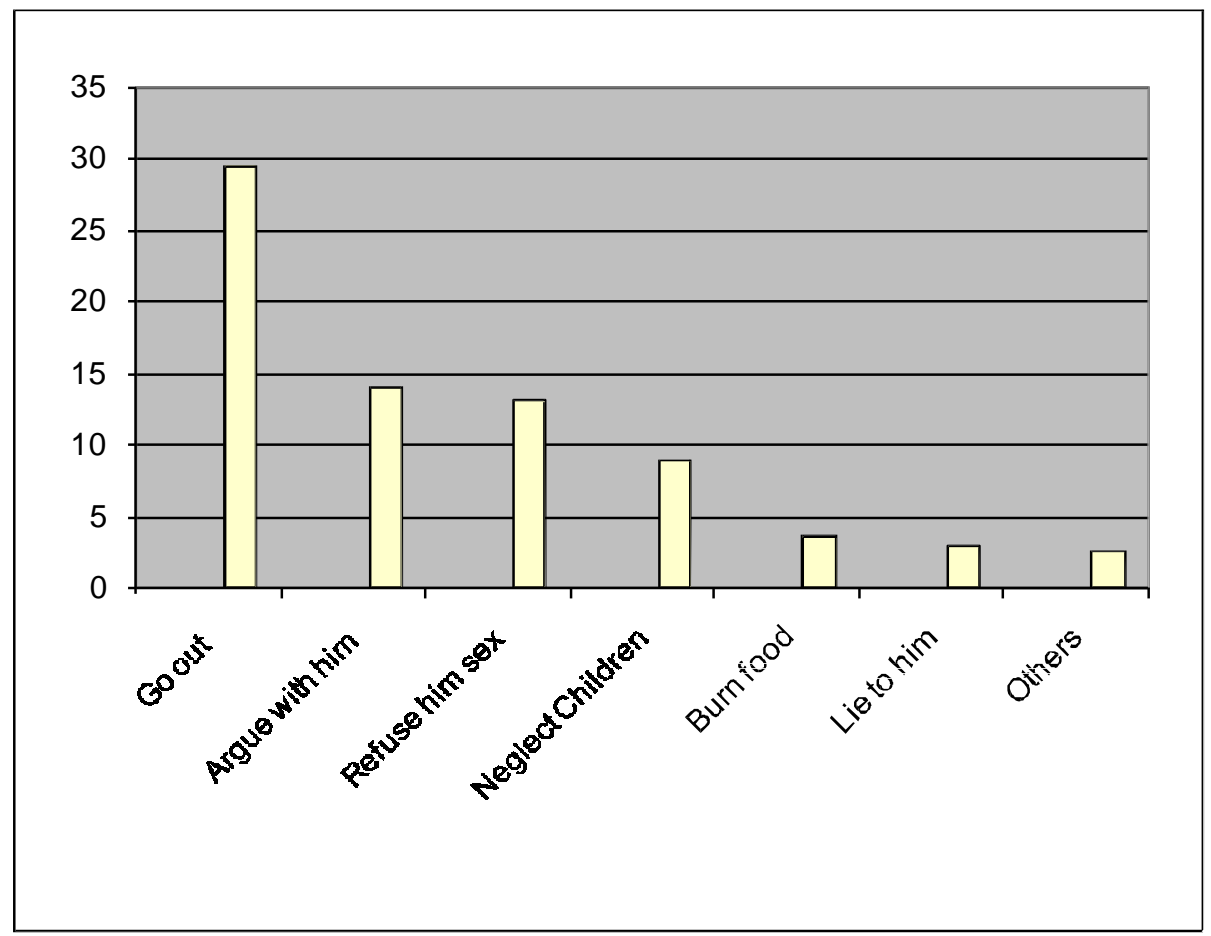

Figure 1: Justification for Violence against Women (in percentage)

\section{Socio-Economic Status of Women and Maternal Health Status}

Table 4 presents information on the effects of women's socioeconomic status on their health status, categorized as good, moderate and poor. The table indicates that about 40 percent of divorced, separated, or widowed (DSW) women have good health status compared with 34 percent of those who are currently married and 31 percent of never married women. The data show that ever married women have better maternal health status in comparison to single mothers. However, the chi-square test of association shows that there is no significant relationship between marital status and maternal health outcome. 
Table 4: Distribution of respondents by socio economic status and maternal health outcome

\begin{tabular}{|c|c|c|c|c|c|c|c|}
\hline \multirow{2}{*}{$\begin{array}{l}\text { Socio economic } \\
\text { Status }\end{array}$} & \multicolumn{4}{|c|}{ Maternal Health Status } & \multirow[t]{3}{*}{$\mathbf{X}^{2}$} & \multirow[t]{3}{*}{ Df } & \multirow[t]{2}{*}{$\mathbf{P}$} \\
\hline & Good & Moderate & Poor & Total & & & \\
\hline \multicolumn{6}{|l|}{ Marital Status } & & \\
\hline Single & 27 & 43 & 16 & 86 & \multirow{7}{*}{7050} & \multirow{7}{*}{4} & \multirow{7}{*}{ nke } \\
\hline & $31.4 \%$ & $50.0 \%$ & $18.6 \%$ & $100.0 \%$ & & & \\
\hline Married & $\begin{array}{c}183 \\
33.6 \%\end{array}$ & $\begin{array}{c}322 \\
57.7 \%\end{array}$ & $\begin{array}{c}58 \\
10.4 \%\end{array}$ & $\begin{array}{c}563 \\
100.0 \%\end{array}$ & & & \\
\hline \multirow[t]{2}{*}{ DSW } & 58 & 76 & 13 & 174 & & & \\
\hline & $39.5 \%$ & $51.7 \%$ & $8.8 \%$ & $100.0 \%$ & & & \\
\hline \multirow[t]{2}{*}{ Total } & 263 & 441 & 87 & 791 & & & \\
\hline & $33.6 \%$ & $52.9 \%$ & $12.6 \%$ & $100.0 \%$ & & & \\
\hline \multicolumn{8}{|c|}{ Educational Qualification } \\
\hline \multirow[t]{2}{*}{ No schooling } & 68 & 95 & 22 & 185 & & & \\
\hline & $36.8 \%$ & $51.4 \%$ & $11.9 \%$ & $100.0 \%$ & & & \\
\hline \multirow{2}{*}{ Primary } & 82 & 126 & 24 & 232 & & & \\
\hline & $35.3 \%$ & $54.3 \%$ & $10.4 \%$ & $100.0 \%$ & & & \\
\hline \multirow[t]{2}{*}{ Secondary } & 66 & 130 & 24 & 220 & & & \\
\hline & $30.0 \%$ & $59.1 \%$ & $10.9 \%$ & $100.0 \%$ & 3.639 & 6 & .727 \\
\hline \multirow[t]{2}{*}{ Tertiary } & 47 & 90 & 17 & 154 & & & \\
\hline & $30.5 \%$ & $58.4 \%$ & $11.0 \%$ & $100.0 \%$ & & & \\
\hline \multirow[t]{2}{*}{ Total } & 264 & 441 & 87 & 791 & & & \\
\hline & $33.2 \%$ & 55.8 & $11.0 \%$ & $100 \%$ & & & \\
\hline \multicolumn{8}{|l|}{ Occupation } \\
\hline \multirow[t]{2}{*}{ Trader } & 52 & 123 & 24 & 199 & & & \\
\hline & $26.1 \%$ & $61.8 \%$ & $12.1 \%$ & $100.0 \%$ & & & \\
\hline \multirow[t]{2}{*}{ Farmer } & 119 & 196 & 32 & 347 & & & \\
\hline & $34.3 \%$ & $56.5 \%$ & $9.2 \%$ & 100.05 & & & \\
\hline \multirow[t]{2}{*}{ Civil Servant } & 66 & 102 & 24 & 192 & 13.80 & & \\
\hline & $34.4 \%$ & $53.1 \%$ & $12.5 \%$ & $100.0 \%$ & 4 & $\mathrm{u}$ & נכט. \\
\hline \multirow[t]{2}{*}{ Others } & 26 & 20 & 7 & 53 & & & \\
\hline & $49.1 \%$ & $37.7 \%$ & $13.2 \%$ & $100.0 \%$ & & & \\
\hline Total & 263 & 441 & 87 & 791 & & & \\
\hline & $35.0 \%$ & $52.5 \%$ & $12.5 \%$ & $100.0 \%$ & & & \\
\hline Last Month Income & & & & & & & \\
\hline$<\mathrm{N} 1,000$ & 100 & 148 & 36 & 284 & & & \\
\hline & $32.2 \%$ & $52.1 \%$ & $12.7 \%$ & $100.0 \%$ & & & \\
\hline $\mathrm{N} 2,000-\mathrm{N} 5,000$ & 70 & 133 & 19 & 222 & & & \\
\hline & $31.5 \%$ & $59.9 \%$ & $12.4 \%$ & $100.0 \%$ & & & \\
\hline N5100-N10,000 & 43 & 91 & 19 & 153 & & & \\
\hline & $28.1 \%$ & $59.1 \%$ & $12.4 \%$ & $100.0 \%$ & 0707 & Q & $2 n_{1}$ \\
\hline $\mathrm{N} 10,100-\mathrm{N} 15,000$ & 28 & 46 & 6 & 80 & & & \\
\hline & $35.0 \%$ & $57.5 \%$ & $7.5 \%$ & $100.0 \%$ & & & \\
\hline$>\mathrm{N} 16,000$ & 22 & 23 & 7 & 52 & & & \\
\hline & $42.3 \%$ & $44.6 \%$ & $13.5 \%$ & $100.0 \%$ & & & \\
\hline Total & 263 & 441 & 87 & 791 & & & \\
\hline & $33.8 \%$ & $54.5 \%$ & $11.7 \%$ & $100.0 \%$ & & & \\
\hline
\end{tabular}




\begin{tabular}{llcccccc}
\hline Age at First birth & & & & & & & \\
$<15 y r s$ & 31 & 48 & 13 & 92 & & & \\
& $33.7 \%$ & $52.2 \%$ & $14.1 \%$ & $100.0 \%$ & & & \\
$15-19 y r s$ & 103 & 161 & 23 & 287 & & & \\
& $35.9 \%$ & $56.1 \%$ & $8.0 \%$ & 100.05 & 14.68 & 6 & .008 \\
$20 y r s$ & 120 & 224 & 43 & 387 & 4 & & \\
& $31.0 \%$ & $57.9 \%$ & $11.1 \%$ & $100.0 \%$ & & & \\
Total & $\mathbf{2 5 4}$ & $\mathbf{4 3 3}$ & $\mathbf{7 9}$ & $\mathbf{7 9 1}$ & & & \\
& $\mathbf{3 3 . 5 \%}$ & $\mathbf{5 5 . 4 \%}$ & $\mathbf{1 1 . 1 \%}$ & $\mathbf{1 0 0 . 0 \%}$ & & & \\
\hline
\end{tabular}

The Table further examines the relationship between educational qualification and maternal health status. The findings do not support a clear-cut relationship between educational qualification and maternal health status even though education generally influences people's perceptions and dispositions towards different activities, including health activities and behaviour. This unexpected result need to be further explored. The relationship between monthly income and maternal health status is also examined. Although there is no statistical association between monthly income and maternal health outcome, women with higher earnings perform better in terms of maternal health outcome relative to those with lower earnings. Women earning N16, 000 had the highest percentage of good maternal health status (42\%) compared to about 30 percent of those earning less than $\$ 1,000$ monthly.

The relationship between age at first birth and maternal health status shows that women who married at age 15-19 years have better health status than those who married at below 15 years and those who married after age 20 years. Considering this graduation from the younger to older ages, it is obvious as indicated by the Pearson chi square test of association that there is a significant relationship between age at first birth and maternal health status.

\section{Household Decision-Making and Maternal Health}

Joint household decision-making between husband and wife produces better maternal health status. Table 5 below displays the relationship between household decision-making and maternal health. It shows that when both the wife and husband jointly decide on the number of children to have, and when to have them, women tend to have better maternal health outcome relative to when each of them decides separately. Furthermore, the table indicates that women, who take decision themselves to seek medical help when sick, and those who take decisions on how to spend their money, tend to have better health status than those who leave these decisions for their husbands to take. These relationships are statistically significant. 
Table 5: Distribution of respondents by household decision and maternal health status

\begin{tabular}{|c|c|c|c|c|c|c|c|}
\hline \multirow[b]{2}{*}{$\begin{array}{l}\text { Who decides on No. of } \\
\text { Children }\end{array}$} & \multicolumn{4}{|c|}{ Maternal Health Status } & \multirow[t]{3}{*}{$\mathbf{X}^{2}$} & \multirow[t]{3}{*}{ Df } & \multirow[t]{2}{*}{$\mathbf{P}$} \\
\hline & Good & Moderate & \multirow{2}{*}{$\begin{array}{c}\text { Poor } \\
23 \\
13.1 \%\end{array}$} & \multirow{2}{*}{$\begin{array}{c}\text { Total } \\
175 \\
100.0 \%\end{array}$} & & & \\
\hline Myself & $\begin{array}{c}49 \\
28.0 \%\end{array}$ & $\begin{array}{c}103 \\
58.9 \%\end{array}$ & & & & & \\
\hline My Husband & $\begin{array}{c}41 \\
27.3 \%\end{array}$ & $\begin{array}{c}95 \\
63.3 \%\end{array}$ & $\begin{array}{c}14 \\
9.3 \%\end{array}$ & $\begin{array}{c}150 \\
100.0 \%\end{array}$ & \multirow[b]{2}{*}{ Y.J01 } & \multirow[b]{2}{*}{ u } & \multirow[b]{2}{*}{$.11 \mathrm{~J}$} \\
\hline Both of Us & $\begin{array}{c}161 \\
37.2 \%\end{array}$ & $\begin{array}{c}225 \\
52.0 \%\end{array}$ & $\begin{array}{c}47 \\
10.9 \%\end{array}$ & $\begin{array}{c}433 \\
100.0 \%\end{array}$ & & & \\
\hline \multicolumn{8}{|c|}{ Who Decides on When to have children } \\
\hline My Husband & $\begin{array}{c}39 \\
24.2 \%\end{array}$ & $\begin{array}{c}104 \\
64.6 \%\end{array}$ & $\begin{array}{c}18 \\
11.2 \%\end{array}$ & $\begin{array}{c}161 \\
100.0 \%\end{array}$ & \multirow{3}{*}{14.197} & \multirow{3}{*}{8} & \multirow{3}{*}{.091} \\
\hline Myself & $\begin{array}{c}45 \\
32.6 \%\end{array}$ & $\begin{array}{c}75 \\
54.3 \%\end{array}$ & $\begin{array}{c}18 \\
13.0 \%\end{array}$ & $\begin{array}{c}138 \\
100.0 \%\end{array}$ & & & \\
\hline Both of Us & $\begin{array}{c}160 \\
35.4 \%\end{array}$ & $\begin{array}{c}246 \\
54.4 \%\end{array}$ & $\begin{array}{c}46 \\
10.2 \%\end{array}$ & $\begin{array}{c}452 \\
100 \%\end{array}$ & & & \\
\hline \multicolumn{8}{|c|}{ When you felt discomfort, What do you do? } \\
\hline Wait for husband & $\begin{array}{c}53 \\
32.0 \%\end{array}$ & $\begin{array}{l}94 \\
55.3 \%\end{array}$ & $\begin{array}{c}23 \\
13.5 \%\end{array}$ & $\begin{array}{c}170 \\
100.0 \%\end{array}$ & \multirow[b]{2}{*}{15.523} & \multirow[b]{2}{*}{4} & \multirow[b]{2}{*}{.000} \\
\hline Seek med. Help & $\begin{array}{c}185 \\
58.1 \%\end{array}$ & $\begin{array}{c}333 \\
57.6 \%\end{array}$ & $\begin{array}{c}60 \\
10.4 \%\end{array}$ & $\begin{array}{c}578 \\
100.0 \%\end{array}$ & & & \\
\hline \multicolumn{8}{|c|}{ Who decides on how to spend your earnings } \\
\hline Myself & $\begin{array}{c}142 \\
39.1 \%\end{array}$ & $\begin{array}{c}215 \\
53.1 \%\end{array}$ & $\begin{array}{c}48 \\
11.9 \%\end{array}$ & $\begin{array}{c}405 \\
100.9 \%\end{array}$ & \multirow[b]{2}{*}{$15 . \supset 08$} & \multirow[b]{2}{*}{4} & \multirow[b]{2}{*}{. voo } \\
\hline My Husband & $\begin{array}{c}97 \\
30.2 \%\end{array}$ & $\begin{array}{c}199 \\
62.0 \%\end{array}$ & $\begin{array}{c}25 \\
7.8 \%\end{array}$ & $\begin{array}{c}321 \\
100.0 \%\end{array}$ & & & \\
\hline \multicolumn{8}{|c|}{ Who has final say on your Health? } \\
\hline Myself & $\begin{array}{c}81 \\
30.0 \%\end{array}$ & $\begin{array}{c}151 \\
55.9 \%\end{array}$ & $\begin{array}{c}38 \\
14.1 \%\end{array}$ & $\begin{array}{c}270 \\
100.0 \%\end{array}$ & & & \\
\hline My Husband & $\begin{array}{c}74 \\
37.6 \%\end{array}$ & $\begin{array}{c}107 \\
54.3 \%\end{array}$ & $\begin{array}{c}16 \\
8.1 \%\end{array}$ & $\begin{array}{c}197 \\
100.05\end{array}$ & 8.614 & 6 & .186 \\
\hline Both of Us & $\begin{array}{c}92 \\
31.8 \%\end{array}$ & $\begin{array}{c}167 \\
57.8 \%\end{array}$ & $\begin{array}{c}30 \\
10.4 \%\end{array}$ & $\begin{array}{c}289 \\
100.0 \%\end{array}$ & & & \\
\hline
\end{tabular}

\section{Communal Practices and Maternal Health}

Table 6 examines the relationship between sociocultural practices and maternal health status. Communal practices include issues such as child marriage, low status accorded women in the society and son preference. The table indicates that those who got married at an age younger than 15 years had very poor maternal health outcome in comparison to those who married later. It is evident from the table that there is a strong and consistent positive association between age at marriage and maternal health status, the $\mathrm{X}^{2}=31.321 ; \mathrm{df}=4 ; \mathrm{p}<.05$ is 
significant. It follows that early marriage age is inimical to the health status of women.

Table 6: Distribution of Respondents by Socio cultural Practices and Maternal Health Status

\begin{tabular}{|c|c|c|c|c|c|c|c|}
\hline \multirow[t]{2}{*}{$\begin{array}{l}\text { Harmful Cultural } \\
\text { Practices }\end{array}$} & \multicolumn{4}{|c|}{ Maternal Health Status } & \multirow[t]{2}{*}{$X^{2}$} & \multirow[t]{2}{*}{ Df } & \multirow[t]{2}{*}{$\mathrm{P}$} \\
\hline & Good & Moderate & Poor & Total & & & \\
\hline \multicolumn{8}{|l|}{ Age at Marriage } \\
\hline$<15 \mathrm{yrs}$ & 135 & 132 & 12 & 279 & & & \\
\hline & $16.4 \%$ & $16.0 \%$ & $1.5 \%$ & $33.9 \%$ & & & \\
\hline$>16 y r s$ & 273 & 219 & 52 & 544 & & & \\
\hline & $33.2 \%$ & $26.6 \%$ & $6.3 \%$ & $66.1 \%$ & 31.321 & 4 & .000 \\
\hline Total & 408 & 351 & 64 & 823 & & & \\
\hline & $49.6 \%$ & $42.6 \%$ & $7.8 \%$ & $100.0 \%$ & & & \\
\hline \multicolumn{8}{|l|}{ Position of Women } \\
\hline Important & $\begin{array}{c}226 \\
27.5 \%\end{array}$ & $\begin{array}{c}151 \\
18.3 \%\end{array}$ & $\begin{array}{c}18 \\
2.2 \%\end{array}$ & $\begin{array}{c}395 \\
48.0 \%\end{array}$ & & & \\
\hline Not Important & $\begin{array}{c}182 \\
22.1 \%\end{array}$ & $\begin{array}{c}200 \\
24.3 \%\end{array}$ & $\begin{array}{c}46 \\
5.6 \%\end{array}$ & $\begin{array}{c}428 \\
52.0 \%\end{array}$ & 23.601 & 4 & .000 \\
\hline Total & $\begin{array}{c}408 \\
49.6 \%\end{array}$ & $\begin{array}{c}351 \\
42.6 \%\end{array}$ & $\begin{array}{c}64 \\
7.8 \%\end{array}$ & $\begin{array}{c}823 \\
100.0 \%\end{array}$ & & & \\
\hline \multicolumn{8}{|c|}{ Which Sex of Child is Preferred? } \\
\hline Male child & $\begin{array}{c}215 \\
26.1 \%\end{array}$ & $\begin{array}{c}189 \\
23.0 \%\end{array}$ & $\begin{array}{c}42 \\
5.1 \%\end{array}$ & $\begin{array}{c}446 \\
51.2 \%\end{array}$ & & & \\
\hline Female child & $\begin{array}{c}193 \\
23.5 \% \\
\mathbf{4 0 8}\end{array}$ & $\begin{array}{c}162 \\
19.7 \%\end{array}$ & $\begin{array}{c}22 \\
2.7 \% \\
\mathbf{6 4}\end{array}$ & $\begin{array}{c}377 \\
45.8 \%\end{array}$ & 23.222 & 4 & .000 \\
\hline Total & $49.6 \%$ & $\begin{array}{r}551 \\
42.6 \%\end{array}$ & $\begin{array}{c}04 \\
7.8 \%\end{array}$ & $\begin{array}{c}823 \\
100.0 \%\end{array}$ & & & \\
\hline
\end{tabular}

Table 6 also shows a consistent relationship between positive perception of the status of women in the society and their health status. Women with positive perception of the status of women have better health status than those with negative perception. This relation is statistically significant $\left(\mathrm{X}^{2}\right.$ value of 23,601). It is also evident from the table that women who maintain the son preference culture of the study area tend to have better health status. However, it should be noted that women who have preference for daughters may be those who already have more sons and are looking for daughters to attain their family size goals.

\section{Multivariate Analysis}

Data in this section are subjected to multivariate analysis involving logistic regression (Table 7). Three sets of independent variables were regressed on the dependent variable (Maternal Health Status). This involves the recategorisation of the dependent variable into ' 0 ' and ' 1 ', where ' 1 ' is the likelihood of good maternal health and ' 0 ' is the likelihood of poor maternal 
health. The odds ratio significantly greater than one indicates that women with the attribute(s) are likely to have or experience good maternal health than the reference category, while a relative risk odds ratio significantly lesser than one indicates that women with this attributes are likely to have poor maternal health status.

\section{Table 7: Logistic Regression on Cultural Practices and Maternal Health}

\begin{tabular}{|c|c|}
\hline Categories & Odds Ratio \\
\hline \multicolumn{2}{|l|}{ Marital status } \\
\hline Single (ref) & 1.00 \\
\hline Married & $1.534 *$ \\
\hline Formerly Married & $1.298^{*}$ \\
\hline \multicolumn{2}{|l|}{ Age } \\
\hline$<25$ (ref) & 1.00 \\
\hline $25-39$ & 0.998 \\
\hline $40+$ & 1.139 \\
\hline \multicolumn{2}{|l|}{ Educational Qualification } \\
\hline No schooling (ref) & 1.00 \\
\hline Primary school & $1.077^{*}$ \\
\hline Secondary\& above & $1.091^{*}$ \\
\hline \multicolumn{2}{|l|}{ Monthly income } \\
\hline$<\mathrm{N} 1,000$ (ref) & 1.00 \\
\hline N2000-N5000 & $1.194 *$ \\
\hline \multirow{2}{*}{\multicolumn{2}{|c|}{ Age at first Birth }} \\
\hline & \\
\hline$<15$ yrs (ref) & 1.00 \\
\hline $15-19$ yrs & $0.388^{*}$ \\
\hline $20+$ & $1.854^{*}$ \\
\hline \multicolumn{2}{|l|}{ Domestic Violence } \\
\hline Violence (ref) & 1.00 \\
\hline No violence & $1.746 *$ \\
\hline \multicolumn{2}{|l|}{ Cultural Practices } \\
\hline Harmful (ref) & 1.00 \\
\hline Not Harmful & $1.783^{*}$ \\
\hline $\begin{array}{l}\text { Household Decision on maternal } \\
\text { health }\end{array}$ & \\
\hline Husband (ref) & 1.00 \\
\hline Self & 1.141 \\
\hline Joint Decision & $1.887^{*}$ \\
\hline
\end{tabular}

The table above indicates that married women and formerly married women are more likely to experience better maternal health status relative to never married mothers, as indicated by significant odds ratio. Older mothers tend to have better health status than those who are less than 25 years, although 
the relationship is not significant. Maternal education shows a positive relationship with maternal health, with women with primary and secondary or higher education having better health status than those with no formal education. Income also indicates that those with higher monthly are more likely to have better health status compared with the reference category (those who earn below $\$ 1000$ a month). Women who had their first children when they were 20 years and above have the best maternal health status, followed by those who had their first birth at 15-19 years, with who had their first birth at below 15 years having the worst health status. The relation between age at marriage and maternal health is significant, an indication that early childbearing engenders the health of mothers. Domestic violence significantly impairs maternal health status as indicated in the table. Women who did not experience violence had odds of 1.746 . It is also instructive that women who do not engage in harmful cultural practices tend to have better health status than those who do. Finally, joint decisions in relation to maternal health are more likely to engender better health outcome relative to sole decisions by husbands, as the odds ratio indicates.

\section{Discussion of Findings}

The study shows a comparatively high percentage of single mothers, and the age at first birth in the study area is predominantly early. The research also found a high level of sexual permissiveness among the people because many young women 15 years or below reported to have given birth in the past year, most of whom were still in their parents' home, in other words, not yet married. With respect to maternal health status, the study found that young and unmarried women have the worse maternal health status relative to older and ever married women.

The educational qualification of respondents showed a relatively high level of literacy among women in the study area compared to the national female literacy rate of 35 percent. The high proportion of the population with secondary school or higher qualification means that women in the study area are knowledgeable about maternal health issues. Besides, the high number of educated women indicates that they are potential change agents in the rural area which advantageous to maternal health. The regression shows that maternal health status improves with maternal education and monthly income, which indicates that education and income confers better health behavior and perhaps better manageability of the environment, including appropriate action when sick.

The age at first birth in the study area is very early and negatively affects women's health status. Apart from early marriage, an important reason for early child bearing is the predominance of poor, young women in the rural area, who are often enticed by the financial assistance from the male folk, which predisposes them to early pregnancy and poor maternal health. The logistic regression revealed a strong and significant relationship between age at first birth and maternal health. Respondents who had first babies when they 
were above 20 years have better maternal health than those who had them earlier. Women who had their babies later are most likely to experience good maternal health status compared to those who had their babies earlier.

Violence against women is common among women in the study area. The majority of women had suffered one form of violence or the other in the hands of an intimate partner in the past year. Even in pregnancy, some women reported suffering violence in the hands of their husbands; needless to say, this could be inimical to their health condition. Despite the fact that most people condemned violence against women, about 50 percent of the respondents posited that the man was justified in abusing his wife if the woman was wrong, and that an act of violence is meted out in order to correct rather than punish her. Intimate partner violence is injurious to the health of the women who are at the receiving end, as suggested by the significantly higher odds ratio (better health) a mong women who have not experienced violence in the past year.

Apart from intimate partner violence, the situations faced by women in the household with respect harmful communal practices and decision-making are important determinants of maternal health. The social consequences of culturally improper behavior by women within the household cycle are inimical to self expression and actions that could improve maternal and child health. As De Zaldwondo et al. (1989) have observed, the fear of social consequences (being beaten, divorced/abandoned, and neglected) tends to take priority over the fears of health consequences of culturally inappropriate behavior or action. This study reinforced the above assertion by indicating that male dominance in decision-making exposes women to poor maternal health status, whereas joint decision-making between husbands and wives produces better maternal health outcome. Women who are involved in culturally harmful behaviors tend to have worse health status than their sisters who are not involved in such practices.

\section{Recommendations}

The study has established that maternal health outcome among the people of Northern Cross River State is invariably tied to the household environmental circumstances as well as the structural community condition. The implication, therefore, is that recommendations to improve maternal health should relate to the specific environmental condition and the community systems to improve on maternal health outcome. Community level health sensitization and health education in rural area will go a long in mitigating the poor health outcomes evident for a large segment of the rural population. The household health environment will be greatly improved though improved household waste and sanitary disposal, improved water supply and more hygienic mode of food preparation and handling. Deliberate effort should be made to engender more positive male role in maternal health by discouraging inimical community 
mores, intimate partner violence, female genital mutilation, early marriage and women's involvement in decisions concerning their health and wellbeing.

Improving maternal health is one of the eight Millennium Development Goals (MDGs) of the United Nations. The study has shown that effort towards achieving better health status for women has not been extensive and successful in the rural areas. The relevant agencies concerned with achieving the MDGs and reproductive health should realize that their efforts have not achieved the desired results in the rural areas generally and the study area particularly. This calls for more concerted programmatic efforts targeted at rural communities. In particular, the provision of functional rural health facilities, adequately staffed, will bring modern health care services nearer to the people and at affordable cost. To be sure, this will help to reduce delays in seeking health care services which have been identified as the main causes of maternal health complications and death during child birth.

\section{References}

Caldwell, J.C. 1979. Education as a Factor in Mortality Declines: An Examination of Nigeria Data. Population Studies, 33(3): 395-414. Cochran, W.G. 1977. Sampling Techniques. New York: John Wiley \& Sons. Diallo,

A.B. 1991. "A Tora Mousso Kele La" A Call Beyond Duty Often

Omitted Root causes of Maternal Mortality in West Africa. Center for Population and Family Health, Columbia University.

De Zalduindo, B.O.; Msamanga, G.I. \& Lincoln, C. 1989. AIDS in Africa: Diversity in the Global Pandemic. Daedalus: 118 (3):165 - 2004.

Gyimah, S.O. 2002. Dynamics of Spacing and Timing of Births in Ghana Population Studies Centre Discussion Paper, Number 02-04. The University of Western Centario, London, Ontario.

Kettle, B. 1996. Women, Health and the Environment. Social Science and Medicine. 42 (10): 1367-1379.

Kyomuhendio, G.B. 2004. Cultural and Resource Determinant of Severe Maternal Morbidity: Lessons from Some "Near Miss" Experiences. African Sociological Review. 8(1): 67-82.

Mechanic, D. \& Newton, M. 1996. Some Problems of Morbidity Data. Journal of Public Health, (18):569.

Mosley, W.H. \& Chen, L.C. 1984. An Analytical Framework for the Study of Child Survival in Developing Countries. Child Survival Strategies for Research, Supplement to Population and Development Review, 10: 25-45.

National Population Commission (NPC) (Nigeria) and ORP Macro. 2004. Demographic and Health Survey 2003, Calverton, Maryland: NPC and ORC Macro.

National Population Commission (NPC) (Nigeria) and ORP Macro. 2008. Demographic and Health Survey 2008, Calverton, Maryland: NPC and ORC Macro. 
Ross, J.; Stover, J. \& Adelaja, A. 2005. Profiles of Family Planning and Reproductive Health Programme in (116 Countries), $2^{\text {nd }}$ Edition Islastonbury: C.T. Futures Group.

Sadana, R. 2000. Measuring Reproductive Health: Review of Community based Approaches to Assessing Morbidity, Geneva: WHO.

Ujah, I.A.O; Aisien, O.A.; Mutihir, D.J.; Vanderjagt, B.J.; Glew, R.H. \& Uguru, V.E. 2005. Factors Contributing To Maternal Morality in North Central Nigeria: A Seventeen Year Review. African Journal of Reproductive Health, 9(3): 27-40.

United Nations, 2007. The Millennium Development Goals Report 2007. http://www.un.org/millenniumgoals/pdf/mdg2007.Retrived 2/03/2010

UNDP, UNICEF, \& UNPFA. 2000. Http/; www.unfpabout.org/report04 /reducing. Retrieved 28/1/07.

Woolsey, T.D.; Lawrence, P.S.; Balanuth, E. 1999. Of Chronic Diseases Prevalence: Data from Community Based Surveys. American Journal of Public Health, 1631-1637.

Zapka, J.G. 1999. Mammograph: Using Surveys Graphically for Diverse Women: The Accuracy of Surveys. Journal of Public Health, 8(6) 86-94. 